\title{
A KLEPTOPARASITIC CHASE BY BROWN PELICANS ON A WESTERN GULL
}

DAVID VANDER PLUYM, 2841 McCulloch Blvd N \#1, Lake Havasu City, Arizona 86403; dvanpluym@gmail.com

Interspecific kleptoparasitism, or the stealing of food from other species, is fairly widespread among birds, most frequently reported for seabirds, especially among the Charadriiformes (Brockman and Barnard 1979, Furness 1987, lyengar 2008). Though most kleptoparasitic species engage in this behavior facultatively, some (especially within the Charadriiformes) may be obligate kleptoparasites during a particular season and potentially throughout the year (Iyengar 2008). Within the family Pelecanidae it has been infrequently reported in the literature.

The ecology and behavior of seabirds meet many of the ecological factors proposed for the evolution of kleptoparasitism, including open habitat, feeding in mixed-species groups, scavenging, and the host's habits being predictable (Brockman and Barnard 1979, Paulson 1985, lyengar 2008). Though kleptoparasitism often involves a larger species stealing food from a smaller species, the Brown Pelican (Pelecanus occidentalis) is perhaps better known as the victim of kleptoparasitism by smaller gulls than vice versa, with several species of gulls and terns reported to steal from it (Shields 2014).

The Brown Pelican was the first species of pelican reported to kleptoparasitize (Sefton 1950, Brockmann and Barnard 1979), and this behavior has since been reported in the Americas by the closely related Peruvian Pelican ( $P$. thagus) (Duffy 1980 ) and the American White Pelican (P. erythrorhynchos) (O'Malley and Evans 1983, Anderson 1991). Reports of kleptoparasitic attacks by the Brown Pelican have appeared to be isolated incidents. In the Peruvian Pelican, however, Duffy (1983) reported that $18 \%$ of attempts to obtain prey involved piracy. Most reported kleptoparasitic attacks by the Brown Pelican and closely related Peruvian Pelican have been in mixed feeding flocks where the pelican is sitting on the water and grabs with its bill or otherwise attacks a nearby species, getting it to drop its food (Sefton 1950, Duffy 1980, Lanciani 2000). This is especially common in situations where the birds are feeding on offal being thrown by people, though it occurs regularly in "wild" situations as well (D. Anderson pers. comm.). The Brown Pelican's target species have included the Double-crested Cormorant (Phalacrocorax auritus) and unidentified gulls (Larus spp.), as well as other Brown Pelicans (D. Anderson pers. comm.). Brown Pelicans have also been observed landing on Great Blue Herons (Ardea herodias) in order to get them to drop food (Bildstein 1980). O'Malley and Evans (1983) observed aerial chases by American White Pelicans in pursuit of food, but I am aware of no such observations involving the Brown Pelican.

At $\sim 16: 30$ on 19 October 2013, during an organized whale watch out of Long Beach, California, in the vicinity of Platform Ellen (Orange County), I noted a subadult (second-cycle) Western Gull (L. occidentalis) chasing an adult Western Gull, followed by two adult Brown Pelicans.

The four birds were first seen flying parallel to the boat, about a kilometer away and only a few meters above the water. The second-cycle Western Gull was close behind the adult Western Gull with the two pelicans following about three meters behind the gulls. The adult gull banked up at roughly a $45^{\circ}$ angle to a height of about 5 meters above the water before gliding back down in an attempt to escape. The second-cycle gull followed closely, and the pelicans also followed, banking up behind the gulls. The lead gull reversed course and quickly made a sharp ascent; through labored flight the pelicans were able to follow. While the second-cycle gull was able to stay on the tail of the lead gull, the pelicans fell back to about 10 meters behind both gulls. However, when the lead gull reversed course again, flying low over the water, both pelicans were able to shorten the gap and eventually overtake the second-cycle gull, placing 


\section{NOTES}

them directly behind the lead gull. Because our set course at this time took us away from the birds, we were not able to see the outcome of this chase, though when last seen the pelicans were lined up directly behind the adult gull, with the lead pelican only about a meter behind. Our observation lasted about 60 seconds, although the kleptoparasitic pursuit likely began before we first noted the birds and continued after we lost sight of them.

Though birds are among the best-known kleptoparasites, most studies have focused on a few species, mainly around seabird colonies (Brockman and Barnard 1979, Furness 1987, lyengar 2008, Flower et al. 2013). Little attention has been paid to comparing kleptoparasitism with alternative foraging techniques or facultative switching (Flower et al. 2013). Although the Brown Pelican has been reported to steal from other birds on the water, this behavior appears to be more common where the bird is scavenging. As my observation appears to be the first report of an active chase by a Brown Pelican it might have represented an opportunistic encounter rather than a regular behavior, although both pelicans were adults, which suggests prior success with this behavior. As the species meets many of the proposed ecological conditions including those listed above and use of "beaters," species that may herd prey for capture (Brockman and Barnard 1979, Paulson 1985, Iyengar 2008), further attention to kleptoparasitism in the Brown Pelican may reveal aerial pursuit as a regular foraging technique.

I thank Lauren Harter for her helpful comments on an early draft of this paper as well as her notes on the observation, Peter Pyle for comments on earlier draft of this paper as well as his comments on aging, and Dan Anderson for his comments on observations of pelicans. Linnea Hall, Western Foundation of Vertebrate Zoology, Dawn Fletcher, and Bob Gill helped accessing literature.

\section{LITERATURE CITED}

Anderson, J. G. T. 1991. Foraging behavior of the American White Pelican (Pelecanus erythrorhynchos) in western Nevada. Colonial Waterbirds 14:166-172; doi 10.2307/1521506.

Bildstein, K. L. 1980. Adult Brown Pelican robs Great Blue Heron of fish. Wilson Bull. 92: 122-123.

Brockmann, H. J., and Barnard, C. J. 1979. Kleptoparasitism in birds. Animal Behavior 27:487-514; doi 10.1016/0003-3472(79)90185-4.

Duffy, D. C. 1980. Patterns of piracy by Peruvian seabirds: A depth hypothesis. Ibis 122:521-525; doi 10.1111/j.1474-919X.1980.tb00910.x.

Duffy, D. C. 1983. The foraging ecology of Peruvian seabirds. Auk 100:800-810.

Flower, T. P., Child, M. F., and Ridley, A. R. 2013. The ecological economics of kleptoparasitism: Pay-offs from self-foraging versus kleptoparasitism. J. Animal Ecol. 82:245-255; doi 10.1111/j.1365-2656.2012.02026.x.

Furness R. W. 1987. Kleptoparasitism in seabirds, in Seabirds: Feeding Ecology and Role in Marine Ecosystems (J. P. Croxall, ed.), pp. 77-100. Cambridge Univ. Press, Cambridge, England.

Iyengar, E. V. 2008. Kleptoparasitic interactions throughout the animal kingdom and a re-evaluation, based on participant mobility, of the conditions promoting the evolution of kleptoparasitism. Biol. J. Linnean Soc. 93:745-762; doi 10.1111/j.1095-8312.2008.00954.x.

Lanciani, C. A. 2000. A kleptoparasitic attack on a Double-crested Cormorant by a Brown Pelican. Fla. Field Nat. 28:195-195.

O'Malley, J. B. E., and Evans R. M. 1983. Kleptoparasitism and associated foraging behavior in American White Pelicans. Colonial Waterbirds 6:126-129; doi $10.2307 / 1520979$. 
Paulson, D. R. 1985. The importance of open habitat to the occurrence of kleptoparasitism. Auk 102:637-639; doi 10.2307/4086662.

Sefton, J. W. 1950. The Brown Pelican as a scavenger. Condor 52:136-137; doi $10.2307 / 1364898$

Shields, M. 2014. Brown Pelican (Pelecanus occidentalis), in The Birds of North America Online (A. Poole, ed.), no. 609. Cornell Lab of Ornithol., Ithaca, NY; http://bna.birds.cornell.edu/bna/species/69; doi:10.2173/bna.609.

Accepted 1 February 2016

\section{WFO'S 41 ${ }^{\text {ST }}$ ANNUAL CONFERENCE- HUMBOLDT COUNTY, CALIFORNIA 28 September-2 October 2016}

PLEASE JOIN US at Western Field Ornithologists' $41^{\text {st }}$ annual conference, 28 September through 2 October 2016 in Fortuna, Humboldt County, California. The beautiful River Lodge Conference Center, on the shores of the Eel River, will be our venue. Four motels and an RV park are within a short walk of the River Lodge, as well as a couple of eateries; more restaurants are available in downtown Fortuna, a few minutes away by car.

As at past conferences, we'll offer full-day field trips on Thursday and Sunday, and half-day field trips and workshops on Friday and Saturday mornings. Science sessions, with short presentations and discussion afterward, will occupy the early afternoons; they will be followed on Friday by Nathan Pieplow's popular bird-sound identification challenge (form a team and join in!) and on Saturday by Ed Harper's always-educational expert panel addressing bird identification through photos. Friday will conclude with WFO's no-cost reception and cash bar-held outside if weather permits - while WFO's annual meeting, banquet, and keynote address, along with a silent auction of donated items to benefit WFO's youth scholarship program, will conclude Saturday's program.

Two dozen different field trips, each offered twice, will explore areas ranging from bottomlands near the northern edge of Del Norte County to Shelter Cove, on the Lost Coast where the King Range meets the Pacific Coast in southernmost Humboldt County. Trips will also range from Humboldt County's headlands, bays, spits, estuaries, coastal lagoons and marshes eastward to dense redwood forests and to interior mountains that approach $6000 \mathrm{ft}$. elevation. Other trips will visit well known coastal or near coastal migrant and vagrant traps in Arcata and Eureka; still others will target species of particular interest, such as Ruffed Grouse, Spotted Owl and Gray Jay, or simply chase whatever rarities have turned up in preceding days.

Our outstanding workshop lineup includes Jon Dunn addressing fall warblers and Stephen Shunk discussing western woodpeckers (both with associated field trips) as well as Peter Pyle explaining everything you've been afraid to know and didn't want to ask about molt. Phil Unitt will lead a bird-specimen workshop, Nathan Pieplow will teach you how to listen to and identify bird sounds more analytically, Kimball Garrett will address field-identification issues posed by non-native birds, and Christine Elder will teach you how to sketch birds in the field.

Friday and Saturday afternoons' science sessions will offer a series of short presentations on a variety of topics, all aimed to interest both serious amateur and professional field ornithologists. Each talk will allot time for questions and discussion with the audience afterward, a hallmark of WFO's conferences. These sessions still have spaces available; if you would like to present, contact Steve Rottenborn at srottenborn@ harveyecology.com for information. Abstracts are due by 30 June.

More information about the conference, and a link to register, are available at www.westernfieldornithologists.org/conference.php. We hope to see you in Fortuna! 